\title{
A COIMPARATIVE STUDY OF TZANAKIS SCORE VS ALVARADO SCORE IN THE DIAGNOSIS OF ACUTE APPEDICITIS
}

KEY WORDS: Acute appendicitis; Tzanakis score; Alvarado score
Dr. Shouryabrata Choudhury

Dr. Bhaskar Sharma*

\section{Dr. Neelanjana Paul}

Assistant Professor, Dept. of General Surgery Silchar Medical College and Hospital Silchar.

Background: Acute appendicitis is the most common cause of sudden abdominal pain requiring surgery. Prolong duration of symptoms before the surgical intervention increases the risk of morbidity and mortality due to perforation. There have been several scoring systems to help the decision making process to reach diagnosis of acute appendicitis. ALVARADO and modified ALVARADO are the two most commonly used system worldwide. This study is being done to assess the accuracy of the TZANAKIS SCORING SYSTEM and ALVARADO SCORING SYSTEM in the diagnosis of acute appendicitis and reduce the rate of negative appendicectomy. Methodology: This was a hospital based prospective observational study conducted on patients admitted in the Department of General Surgery, Silchar Medical college and Hospital. This study was based on the analysis of 100 patients diagnosed to have acute appendicitis and underwent emergency open appendectomy from March 1st ,2020 - August 31st 2020. Aims and objectives: The aim of the present study is to assess the compare the accuracy of TAZANAKIS Scoring system and ALVARDO scoring system in the diagnosis of acute appendicitis. Results: The sensitivity, specificity, positive predictive value and negative predictive value of Tzanakis score was 83.72, 78.57,96.0 and 44.0 respectively and of Alvarado score was 65.1 1,35.71,86.1 and 14.28 respectively. Negative appendicectomy was $14 \%$. Conclusion: Tzanakis scoring system is an effective scoring system to establish the accurate diagnosis of acute appendicitis and helps in reducing negative appendicectomy rate.

\section{INTRODUCTION}

Acute appendicitis is considered to be one of the commonest causes for acute abdomen in any general surgical practice. 1 Appendicitis is preferably treated by appendectomy. The diagnosis of acute appendicitis is essentially clinical although laboratory and radiological investigation aid in the diagnosis. ${ }^{2}$

Due to the heterogenous presentation of acute appendicitis sometimes it becomes difficult to diagnosis and there are various other disease which has similar presentation. Early diagnosis and treatment of acute appendicitis is important to limit its progression to become complicated. Failure to make an early diagnosis is a primary reason for the persistent rate of morbidity and mortality. ${ }^{3}$

A number of clinical and laboratory based scoring systems have been devised to assist diagnosis. The most widely used is the Alvarado score.2 In Alvarado scoring system eight predictive factors are identified to stratify risk of acute appendicitis. Increased score is associated with increased risk for appendicitis.

Another scoring system is Tzanakis scoring system which is a combination of clinical evaluation, ultrasonography and laboratory marker of inflammatory response.4 This system uses 4 variables.

The present study was done to assess the accuracy of the TZANAKIS SCORING SYSTEM and ALVARADO SCORING SYSTEM in the diagnosis of acute appendicitis and the rate of negative appendicectomy.

\section{MATERIAL AND METHOD}

The present study was conducted on patients admitted in the Department of General Surgery, SMCH for a period of 6 months. The study was approved by the Ethical Review Board of SMCH.Written informed consent was taken from each study subject at the time of enrolment.
The present study is a hospital based prospective observational study. This study was based on the analysis of 100 patients diagnosed to have acute appendicitis and underwent emergency open appendectomy from March 1st ,2020 - August 31st 2020. At the time of admission Tzanakis and Alvarado scores were obtained. Emergency appendectomy was done by the open method under spinal or general anesthesia in all cases. Final diagnosis of acute appendicitis was based on histopathological reports.

\section{INCLUSION CRITERIA:}

Patients of all ages and of either sex presenting with acute abdomen will be included in the study.

\section{EXCLUSION CRITERIA:}

1.Patient previously diagnosed with acute appendicitis

2.Pregnant women.

3. Patient with previous history of urolithiasis.

4. Patients with pelvic inflammatory disease.

5. Patients refusing hospitalization.

6. Patients with appendicular abscess, appendicular mass appendicular perforation.

The Alvarado (MANTRELS) score.

\begin{tabular}{|c|c|c|}
\hline \multirow{3}{*}{ Symptoms } & Migratory RIF pain & Score \\
\cline { 2 - 3 } & Anorexia & 1 \\
\cline { 2 - 3 } & Nausea and vomiting & 1 \\
\hline \multirow{3}{*}{ Signs } & Tenderness (RIF) & 2 \\
\cline { 2 - 3 } & Rebound tenderness & 1 \\
\cline { 2 - 3 } & Elevated temperature & 1 \\
\hline Laboratory & Leukocytosis & 2 \\
\cline { 2 - 3 } & Shift to left & 1 \\
\hline Total & & 10 \\
\hline
\end{tabular}

\section{SCORE:}

1-4-DISCHARGE

5-7-OBSERVATION 


\section{7-10-SURGERY}

\section{The Tzanakis Score}

\begin{tabular}{|c|c|}
\hline & Score \\
\hline Signs & 4 \\
\hline $\begin{array}{c}\text { Presence of right lower abdominal } \\
\text { tenderness }\end{array}$ & 3 \\
\hline Rebound tenderness & \\
\hline Laboratory findings & 2 \\
\hline Presence of wbc >12000 & 6 \\
\hline $\begin{array}{c}\text { Presence of positive ultrasound scan } \\
\text { findings of appendicitis }\end{array}$ & 15 \\
\hline Total & \\
\hline
\end{tabular}

Score $>8$-diagnostic of acute appendicitis

\section{RESULTS AND OBSERVATION}

The results are based on the analysis of 100 patients who were diagnosed to have appendicitis and underwent appendectomy. In this study the maximum percentage of belonged to the age group of $21-30$ years. $44 \%$ of the patient belonged to the age group between 31-40 years.

Table 1: Age Distribution

\begin{tabular}{|c|c|c|}
\hline Age (years) & No of cases & Percentage \\
\hline$<20$ & 8 & 8 \\
\hline $\mathbf{2 1 - 3 0}$ & 44 & 44 \\
\hline $\mathbf{3 1 - 4 0}$ & 24 & 24 \\
\hline $\mathbf{4 1 - 5 0}$ & 12 & 12 \\
\hline $\mathbf{5 1 - 6 0}$ & 9 & 9 \\
\hline $\mathbf{6 1 - 7 0}$ & 2 & 2 \\
\hline$>\mathbf{7 0}$ & 1 & 1 \\
\hline
\end{tabular}

Table 2: Alvarado scoring

\begin{tabular}{|c|c|c|c|c|}
\hline \multicolumn{2}{|c|}{} & \multicolumn{3}{|c|}{$\begin{array}{c}\text { Patients confirmed to have } \\
\text { appendicitis on HPE }\end{array}$} \\
\cline { 2 - 5 } \multicolumn{2}{|c|}{} & Yes & No & \\
\hline \multirow{2}{*}{$\begin{array}{c}\text { Alvarado } \\
\text { Score }\end{array}$} & $>7$ & $56(\mathrm{TP})$ & $9(\mathrm{FP})$ & 65 \\
\cline { 2 - 5 } & $<7$ & $30(\mathrm{FN})$ & $5(\mathrm{TN})$ & 35 \\
\hline Total & & 86 & 14 & 100 \\
\hline
\end{tabular}

TP- True positive; TN-True negative; FP-False positive; FNFalse negative

Table3:Tzanakis scoring

\begin{tabular}{|c|c|c|c|c|}
\hline & \multicolumn{3}{|c|}{$\begin{array}{c}\text { Patients confirmed to have appendicitis } \\
\text { on HPE } \\
\end{array}$} \\
\hline & & \begin{tabular}{|l|} 
Yes \\
\end{tabular} & No & \\
\hline \multirow{2}{*}{$\begin{array}{l}\text { Tzanakis } \\
\text { Score }\end{array}$} & $>8$ & 72(TP) & 3(FP) & 75 \\
\hline & $<8$ & 14(FN) & $11(\mathrm{TN})$ & 25 \\
\hline Total & & 86 & 14 & 100 \\
\hline
\end{tabular}

Table 4: Comparison of Alvarado score \& Tzanakis score.

\begin{tabular}{|c|c|c|}
\hline & $\begin{array}{c}\text { Alvarado score } \\
\text { (\%) }\end{array}$ & $\begin{array}{c}\text { Tzanakis Score } \\
\text { (\%) }\end{array}$ \\
\hline Sensitivity & 65.11 & 83.72 \\
\hline Specificity & 35.71 & 78.57 \\
\hline $\begin{array}{c}\text { Positive predictive } \\
\text { value (PPV) }\end{array}$ & 86.1 & 96.0 \\
\hline $\begin{array}{c}\text { Negative predictive } \\
\text { value (NPV) }\end{array}$ & 14.28 & 44.0 \\
\hline
\end{tabular}

Negative appendectomy- $14 \%$

Tzanakis scoring system is better than Alvarado scoring system in terms of sensitivity, specificity, PPV and NPV as compared to Alvarado scoring.

\section{DISCUSSION}

\section{ALVRADO SCORING-}

In this study we found sensitivity, specificity, negative predictive value and positive predictive value of Alvarado scoring system to be $65.11 \%, 35.71 \%, 86.1 \%$ and $14.28 \%$ respectively.

Shashikala V et al found similar results with sensitivity, specificity, negative predictive value and positive predictive value of Alvarado scoring system to be $61.9 \%, 50 \%, 86 \%$ and $15 \%$ respectively. ${ }^{5}$

In a study conducted by Malla BR et al sensitivity, specificity, negative predictive value and positive predictive value of Alvarado scoring system to be $76 \%, 75 \%, 97.2 \%$ and $21.42 \%$ respectively. ${ }^{6}$

Ohle et al. found the sensitivity and specificity of Alvarado scoring system to be $99 \%$ and $81 \%$ respectively.

Murugesan et al found sensitivity, specificity, negative predictive value and positive predictive value of Alvarado scoring system to be $76 \%, 75 \%, 97.2 \%$ and $21.4 \%$ respectively. ${ }^{8}$

\begin{tabular}{|c|c|c|c|c|c|}
\hline & $\begin{array}{l}\text { This } \\
\text { study }\end{array}$ & $\begin{array}{l}\text { Shashikal } \\
\text { a V et al }\end{array}$ & \begin{tabular}{|c|} 
Malla \\
BR et al ${ }^{6}$
\end{tabular} & $\begin{array}{l}\text { Ohle et } \\
\text { al. }^{7}\end{array}$ & $\begin{array}{c}\text { Murugesa } \\
\text { n et al }\end{array}$ \\
\hline $\begin{array}{c}\text { Sensitivit } \\
\mathrm{y}\end{array}$ & $\begin{array}{c}65.11 \\
\%\end{array}$ & $61.9 \%$ & $76 \%$ & $99 \%$ & $76 \%$ \\
\hline $\begin{array}{c}\text { Specificit } \\
\mathrm{y}\end{array}$ & $\begin{array}{c}35.71 \\
\%\end{array}$ & $50 \%$ & $75 \%$ & $81 \%$ & $75 \%$ \\
\hline $\begin{array}{c}\text { Positive } \\
\text { predictiv } \\
\text { e value } \\
\text { (PPV) }\end{array}$ & $86.1 \%$ & $86 \%$ & $97.2 \%$ & - & $97.2 \%$ \\
\hline $\begin{array}{c}\text { Negative } \\
\text { predictiv } \\
\text { e value } \\
\text { (NPV) }\end{array}$ & $\begin{array}{c}14.28 \\
\%\end{array}$ & $15 \%$ & $21.42 \%$ & - & $21.4 \%$ \\
\hline
\end{tabular}

\section{TZANAKIS SCORE-}

In this study we found sensitivity, specificity, negative predictive value and positive predictive value of Tzanakis scoring system to be and $83.72 \%, 78.57 \%, 96 \%$ and $44 \%$ respectively.

Kumar SLA et al found similar results with sensitivity, specificity, negative predictive value and positive predictive value of Tzanakis scoring system to be $85.49,71.43,98.80$ and 15.15 respectively. ${ }^{4}$

Shashikala V et al in a study found the sensitivity, specificity, negative predictive value and positive predictive value of Tzanakis scoring system to be $79.62 \%, 83.3 \%, 97.72 \%$ and $31.25 \%$ respectively. ${ }^{5}$

In a study conducted by Murugesan et al sensitivity, specificity, negative predictive value and positive predictive value of Tzanakis scoring system was found to be $89.6 \%, 75 \%$, $97.5 \%$ and $33.3 \%$ respectively. ${ }^{8}$

Dharmarajan et al in their study showed that the sensitivity, specificity, negative predictive value and positive predictive value of Tzanakis scoring system was $97.59 \%$, 94.11, 98.78 and $88.8 \%$ respectively.

\begin{tabular}{|c|c|c|c|c|c|}
\hline & $\begin{array}{c}\text { This } \\
\text { study }\end{array}$ & $\begin{array}{c}\text { Kumar } \\
\text { SLA et al }\end{array}$ & $\begin{array}{c}\text { Shashikal } \\
\text { a V et al }\end{array}$ & $\begin{array}{c}\text { Muruges } \\
\text { an et al }\end{array}$ & $\begin{array}{c}\text { Dharma } \\
\text { rajan et } \\
\text { al }\end{array}$ \\
\hline Sensitivity & 83.72 & $85.49 \%$ & $79.62 \%$ & $89.6 \%$ & $97.59 \%$ \\
\hline Specificity & 78.57 & $71.43 \%$ & $83.3 \%$ & $75 \%$ & $94.11 \%$ \\
\hline $\begin{array}{c}\text { Positive } \\
\text { predictive } \\
\text { value } \\
\text { (PPV) }\end{array}$ & 96.0 & $98.80 \%$ & $97.72 \%$ & $97.5 \%$ & $98.78 \%$ \\
\hline
\end{tabular}




\begin{tabular}{|c|c|c|c|c|c|}
\hline $\begin{array}{c}\text { Negative } \\
\text { predictive } \\
\text { value } \\
\text { (NPV) }\end{array}$ & 44.0 & $15.15 \%$ & $31.25 \%$ & $33.3 \%$ & $88.8 \%$ \\
\hline
\end{tabular}

\section{CONCLUSION}

The Tzanakis scoring system is a much better diagnostic scoring system for acute appendicitis compared to the Alvarado scoring system. The sensitivity, specificity, positive predictive value and negative predictive value is higher in Tzanakis as compare to the Alvarado scoring system. Negative appendectomy rate can be decreased if Tzanakis scoring system is used for appendectomy.

\section{REFERENCES}

1. Ceresoli M, Zucchi A, Allievi N, Harbi A, Pisano M, Montori G, et al. Acute appendicitis: Epidemiology, treatment and outcomes- analysis of 16544 consecutive cases.World J Gastrointest Surg. 2016;8(10):693.

2. Bailey \& Love's Short Practice of Surgery 27th Edition. Get more medical books and resources at.

3. Alvarado A. A practical score for the early diagnosis of acute appendicitis. Ann Emerg Med. 1986; 15(5):557-64.

4. Lakshminarasimhaiah AKS, A. L. N,M. S. Evaluation of Tzanakis scoring system in acute appendicitis: a prospective study.Int Surg J.2017;4(10):3338.

5. Shashikala V, Hegde H, Victor AJ, Hegde H. Comparative study of Tzanakis score vs Alvarado score in the effective diagnosis of acute appendicitis * Correspondence Info :2016;7(9):418-20.

6. Br M, Batajoo H. Comparison of Tzanakis Score vs Alvarado Score in the Effective Diagnosis of Acute Appendicitis. :5-7.

7. Ohle R, O'Reilly F, O'Brien KK, Fahey T, Dimitrov BD. The Alvarado score for predicting acute appendicitis:A systematic review.BMC Med.2011;9.

8. Study AC, Efficacy OF, Tzanakis OF, With S, In S, Acute D. INTERNATIONAI JOURNAL OF SCIENTIFIC RESEARCH A COMPARATIVE STUDY OF JOURNAL OF SCIENTIFIC RESEARCH A COMPARATIVE STUDY OF
EFFICACY OF TZANAKIS SCORE WITH ALVARADO SCORE IN DIAGNOSING ACUTE APPENDICITIS Surgery R PACHIAPPAN ABSTRACT KEYWORDS : 2017;(5):628-9.

9. S D, R A. A study comparing modified Alvarado score and Tzanakis score for diagnosing acute appendicitis. 2019;6(5):137-41. 